\title{
Communication
}

\section{On Political Correctness}

\author{
Oscar Pérez de la Fuente
}

Department of International Law, Ecclesiastical Law and Philosophy of Law, Carlos III University of Madrid, 28903 Getafe, Madrid, Spain; oscar.perez@uc3m.es

Received: 31 July 2019; Accepted: 24 September 2019; Published: 1 October 2019

check for updates

\begin{abstract}
This paper aims to analyse the arguments in favour and against applying Political Correctness policies on campus, especially on the curricula. The arguments in favour that will be studied are the criticism of the canon and the fair representation of minorities. The arguments against are that Political Correctness is a threat to freedom of expression, academic freedom and its methodology is problematic.
\end{abstract}

Keywords: Political Correctness; University; canon; classics; sexism; racism; homophobia; freedom; equality; diversity

\section{What Is Political Correctness?}

An extension of multiculturalism and the 'politics of identity' have been developed in University issues, especially on American campuses since the 1990s, under the umbrella term: Political correctness (PC, in this paper).

According to Taylor, the 'struggle for recognition' appears after Enlightenment from the competition of two ideals: The well-known principle of equal dignity and the new principle of differentiated identity, which means that "everyone should be recognized(sic) for his or her unique identity." Both ideals are universal, but differentiated identity reacts to ignorance or assimilation to a majority identity (Taylor 1994, p. 38).

The multiculturalism approach criticises minorities' values as being inferior and deviant and majority values as being as normal and neutral. The difference is perceived as a stigma. Young says "traditional politics that excludes or devalues some persons on account of their group attributes assumes an essentialist meaning of difference; it defines groups as having different natures" (Young 1990, p. 157). Instead of this, Young promotes a relational understanding of difference.

'Politics of identity' appears because "sometimes groups seek to cultivate mutual identification among those similarly situated, and in doing so, they may indeed express conflict and confrontation with others who are differently situated, against whom they make claims that they wrongfully suffer domination or oppression" (Young 2002, p. 107). It is possible to distinguish between 'politics of identity' that comprises freedom of expression, the content of curricula, official languages and access to media from most group-conscious political claims for fairness, equal opportunity, and political inclusion, that Young labels as 'politics of difference' (Young 2002, p. 107).

The struggle for recognition of differences, and against assimilation, has called into question some University practices from the perspective of diversity, as part of 'politics of identity', such as: "[C]urricular change, admission standards, fellowship awards, disciplinary codes, hiring and tenure procedures, teachings loads, "useless" time spent on research, accreditation standards" (Wallach Scott 1995, p. 23).

This paper focuses on how political correctness affects academic freedom, in particular, the University curricula. Political correctness is usually presented as a severe criticism of the traditional 
canon because it is based on prejudices and stereotypes of sex, gender, sexual orientation, etc. There are some omissions in that canon because it does not represent the whole human diversity fairly.

As Kimball explains 'canon' "refers to the unofficial, shifting, yet generally recognized(sic) body of great works that have stood the test of time and are acknowledged to be central to complete liberal arts educations" (Kimball 1998, p. 13). Will affirms that all literature that has been considered canonical is suspicious because it includes "disguised or unexamined assumptions and interests of the dominants class, sex, race. Hence culture is oppressive and literary canon is an instrument of domination" (Will 1992, p. 24).

On the other hand, with irony, Bloom expresses that "all literature up to today is sexist, the muses never sang to the poets about liberated women. It's the same old chanson from the Bible and Homer through Joyce and Proust" (Bloom 1987, p. 65). D'Souza put an example of viewpoint represented by the new curriculum: "I begin my course with the basic feminist principle that in a racist, classist, and sexist society we have a swallowed oppressive ways of beings, whether intentionally or not. Specifically, this means that it is not open to debate whether a white student is a racist or a male student is sexist. He/she simply is" (D'Souza 1992, p. 13).

The PC discussion is particularly important in different societies because it forms part of the cultural battles on the hegemony on some values as difference, pluralism, but also freedom and neutrality. The role of majorities and minorities is an important topic in different democracies. Cultural appropriation or reverse discrimination in politics or cultural professions are nowadays controversial issues influenced by PC. In order to understand these current debates in different countries properly, it is interesting to analyse how and when these claims from PC appeared for the first time: In the 1990's on the American campuses. As Doria explains: “American universities are institutions centrally involved in these dynamics of power and knowledge. They also house many stereotypes" (Doria 2017, p. 61).

PC is a complex phenomenon and is usually presented as a double-edged sword. As Perry explains "in no society was it invoked as a genuine standard for sociopolitical practice-so that we might live as if the revolution had already happened — than it was mocked as purist, ideologically rigid and authoritarian" (Perry 1992, p. 77). PC can involve a new orthodoxy that liberates from old prejudices but, for the critics of PC, this new orthodoxy is itself a new form of prejudice with new victims. For example, as explains Magnani. "derived moral agendas are often considered by a large part of public opinion arbitrary, abstract, hypocritical and unjustified challenges to the standards semantics of natural languages of various groups" (Magnani 2016, p. 362).

There is also an ironic connotation of PC that involves a "self-critical dimension of New Left politics, a flexibility, a suspiciousness of orthodoxy of any sort" (Perry 1992, p. 77). The limits of PC usually affect freedom and the capacity to express ideas, for example in a humoristic way. There is an open criticism of PC with some types of humour that seek to be better grounded than the PC perspective. There are different intentions and connotations linked with PC and this quite a controversial point.

Arguments in favour and against PC will now be presented.

\section{Arguments in Favour of PC}

Politics of identity, from a University perspective, could refer to the fair representation of different points of view, especially from minorities, in the curricula beyond the classical canon. As Stimpson states multiculturalism "promises to bring dignity to the dispossessed and self-empowerment to the dispossessed, to recuperate the texts and traditions of ignored groups, to broaden cultural history" (Stimpson 1992, p. 45). This also implies "refusing to reduce the concept of the public to the imperatives of cultural uniformity, elitism, or the imperatives of the job market" (Giroux 1995, p. 298).

\subsection{Criticism of the Canon}

The history of the PC movement began with the controversy at Stanford, and dates back to April, 1986, when members of the Black Students Union complained that the requirement of a year-long 
course for first-year students in Western culture was racist, sexist, and failed to address the needs of minority students or women. It is even reported that one critic of the course declared that it is "not just racist education, it is the education of racists" (Kimball 1998, p. 42).

The demands of multiculturalism for a fair representation of minorities perspective, on Gordon and Lubiano analysis, is that it "requires that the curricula of the 'West', as it is currently understood, be placed under scrutiny and transformed in order to fairly represent the variegated nature of American culture: It requires that materials and knowledge from marginalized(sic) groups be part of degree and are requirements; it requires that 'minority' people be empowered here" (Gordon and Lubiano 1993, p. 251).

Traditionally an exclusion of minorities' voices has been in the canon, or their representation has been prejudiced and stereotyped. Some invisible perspectives and views are usually hidden or misrepresented. PC goes against this situation and argues that the canon is not neutral on race, sex, class or sexual orientation. The next step is to call for a fair representation of the minorities' voices in the University courses. As Searle explains, the argument goes: "[S]ince any policy in the humanities will inevitably have a political dimension, courses in the humanities might as well be explicitly and beneficially political, instead of being disguised vehicles of oppression" (Searle 1993, p. 98).

\subsection{Fair Representation of Minorities}

The consequences of PC have given rise to a new and special awareness and conscientiousness on the treatment of diversity in specific policies on campus. PC, firstly, has impacted on the role of politics in the study of humanities. As Stimpson explains "some scholars who do such studies go the public with their politics and its relation to their academic works. This, in turn, has led to charges that their academic works are 'only' political, especially if their politics are 'left'" (Stimpson 1992, p. 58). PC, secondly, has been relevant in everyday campus life. For example, with the apparition of Women Studies, Latin and Asian Studies and Gay and Lesbian Studies (Stimpson 1992, p. 58).

According to Stimpson, Kimball explains, the traditional view of humanities is elitist, hierarchical, and insufficiently sensitive to differences like "age, class, ethnicity, institution, gender, nation, tribe, race, rank, religion, sexuality", while the multiculturalism involves "treating society as the home of several equally valuable but distinct racial and ethnic groups" (Kimball 1993, p. 82).

Specifically, with regards to curriculum restructuring, Gordon and Lubiano present four areas of concern:

1. All aspects of the University curriculum have to be subjected to critique and reformation in order to ensure that the curriculum reflects not only the presence of multiple cultures in specific bodies of knowledge, but also the ways in which these presences have to be inserted now because of the historical reasons for their absences.

2. A multiculturalist project requires a critique and reformation-not elimination-of generally required traditional courses, such as American history and Texas government in order to reflect the complexities of minority cultures' participation in those discourse and their relation to the ways in which this subject have themselves historically marginalised minority knowledge and engagements.

3. Degree and area requirements should be transformed so that undergraduate students are required to take two minority studies courses. One within the American context and another within the world context.

4. Graduate students should be required to take a course that critiques the formation of disciplinary canon, methodologies and discourses (Gordon and Lubiano 1993, pp. 255-57).

PC on campus, firstly, means the politicisation of Humanities. Howe affirms that "the claim that there can be value-free teaching is a liberal deception or self-deception; so too the claim that there can be texts untouched by social and political bias. Politics or ideology is everywhere, and it is the better part of honesty to admit this" (Howe 1993, p. 167). 
PC on campus, secondly, denounces old prejudices and opens the canon to new voices. Howe states that "wittingly or not, the traditional literary and intellectual canon was based on received elitist ideologies, the values of Western imperialism, racism, sexism, etc. and the teaching of the humanities was marked by corresponding biases. It is now necessary to enlarge the canon so that voices from Africa, Asia, and Latin America can be heard. This is especially important for minority students so that they may learn about their origins and thereby gain in self-esteem" (Howe 1993, pp. 167-68).

$\mathrm{PC}$ is a new approach to diversity that requires some changes in certain University policies. What is at stake here is the extent to which it is justified to restrict some freedoms in order to ensure equality and diversity on the curricula.

\section{Arguments Against PC}

The arguments that PC is a threat to freedom of expression, academic freedom and its methodology is problematic will now be presented.

\subsection{Threat to Freedom of Expression}

There are some criticisms of using PC policies on campus. It could be seen as an "Orwellian nightmare" (Neilson 1995, p. 63). There are also allegations of a new McCarthyism, which followed many of the same tactics and embraced many of the same beliefs as the old McCarthyism (Neilson 1995, p. 63). PC was seen as "leftist totalitarianism" (Neilson 1995, p. 65; Lichev and Hristoskova 2017, p. 20). The conclusion is that the PC movement has resulted in a threat to freedom of expression (Ayim 1998, p. 453).

PC, with its emphasis on anti-racist and anti-sexist politics, is attempting to enact legislation and policies that would outlaw speaking or writing in ways that the PC proponents identify as racist or sexist. But any such legislation or policy would be a gross interference with the right of every citizen to freedom of expression (Ayim 1998, p. 453).

Free speech is a core value in democratic societies. Under certain very restricted conditions, such as incitation to violence or hate, political speech can be limited. Artistic and literary freedoms are also important values, and traditionally, there has been a great debate on the notion of obscenity and the limits of censorship. The following questions should, therefore, be asked: Are there are limits on free speech in literary and academic works because of the demands of PC? Are literary works-fairly-represented in the curricula?

Aristotle argued in favour of the natural subordination of women and slaves and supported a human virtues theory. Kant defended his position that women and non-autonomous people should not have the right to vote, but also supported the human dignity principle. Hobbes, Locke and Rousseau push for the Social Contract theory, but excluded women. Shakespeare, in the Merchant of Venice, was accused of antisemitism. The Bible has been accused of sexism and homophobia.

Should a creator's free speech be limited by PC? Generally speaking, the answer is no, but sometimes it is necessary to analyse the situation on a case by case basis considering the matter and manner of the facts in question. Only in extreme and severe cases can the free speech of a creator be limited.

How should PC affect University courses? The key is proper contextualisation. Shakespeare is often considered a great author, and if a character of his creation is the physical embodiment of a hateful trait, this can be said to be part of his creative liberty. Likewise, Aristotle is viewed as a very important philosopher, despite his ideas on women and slaves. Arguably, the solution is not to exclude Aristotle, Kant, Locke, Hobbes, Rousseau and Locke, but rather to contextualise and properly discuss their ideas.

\subsection{Threat to Academic Freedom}

Academic freedom of specific professors has been diluted with PC policies on campus. D'Souza explains that since race and gender issues are so sensitive, the university leadership often discourages 
faculty from presenting factual material that may provoke or irritate minority students. Several professors who cross the academic parameters of what may be said in the classroom have found themselves the object of organised vilification and administrative penalties. Again, these intellectual curbs do not apply to professors who are viewed as the champions of minority interest - they are permitted overtly ideological scholarship, and are immune from criticism even when they make an excessive or outlandish claim with racial connotations (D'Souza 1991, p. 5).

An example of a PC campaign against a scholar is the recent case of Finnis and homosexuality. He is a retired Professor of Philosophy of Law at the University of Oxford, who usually defends the views of Thomas Aquinas' Natural Law tradition. According to this tradition, the only worthy, reasonable and intrinsically good sex is under a marriage of man and woman. Homosexuality is immoral and unnatural (Finnis 1996, p. 14). There has been a students' campaign against Professor Finnis because of his ideas on homosexuality. Those students claimed he should not teach at the University nor defend those points of view against minorities. He actually defends the traditional view of the Catholic Church on sexuality. For example, he also criticises adultery and masturbation with the same kind of argument that he uses for homosexuality, according to Achinas' view. Arguments for and against these views could be made in an academic debate, but what the PC approach would demand in this case is the expulsion of this professor from the University.

Rothemberg makes an interesting point when she expresses "how ironic is it that those of us seeking to make the curriculum and campus climate less racist, less sexist, less heterosexist, are portrayed as threats to democratic freedoms rather than their champions" (Rothenberg 1993, pp. 267-68). Will offers an answer from the critics of PC: "[S]o is the destination: Political indoctrination supplanting education" (Will 1993, p. 261). Kimball reinforces this idea because "nowadays has been held to furnish gender, race and class as only the appropriate criterion for determining the content of the curriculum and the focus of pedagogical interest" (Kimball 1998, p. 16). Ditakis reinforces the idea: "[T] he threat of this motivates the will to restrict the sayable (as restriction of reality) and the additional radicalization(sic) of utterances (by external politicization(sic) and performative understanding of it)" (Dirakis 2017, p. 22).

The conclusion is that the PC movement has resulted in a threat to academic freedom (Ayim 1998, p. 453). There is a paradox. As Searle points out "no one seems to complain that the great ideas in physics, mathematics, chemistry, and biology, for example, also come in large part from dead European males" (Searle 1993, p. 97). He continues by affirming: "[E]ven in history of philosophy courses - as opposes to general education courses - there is little or no objection to the fact that the great philosophers taught in these courses are mostly white Western males, from Socrates, Plato, and Aristotle through Frege, Russell, and Wittgenstein" (Searle 1993, p. 97).

Searle presents some arguments in favour of the classical view of humanities and against PC policies on campuses:

First, it is not the aim of the education to provide a representation or sample of everything that has been thought and written, but to give students access to works of high quality.

Second, for that very reason, education is by its very nature "elitist" and "hierarchical" because it is designed to enable and encourage the students to discriminate between what is good and what is bad, what is intelligent and what is stupid, what is true and what is false.

Third, the "tradition" is by no means a unified phenomenon, and properly taught, it should impart a critical attitude to the student, precisely because of the variety and intellectual independence of the works being taught and the disagreements among them.

Fourth, of course the humanities have a political dimension at least in the sense that they have political consequences; so does everything else. But it does not follow from the fact that there is a political dimension to humanities-as there is to music, art, gastronomy, and sex, as well as mathematics, philosophy, and physics - that the only, or even the principal, criteria for assessing these efforts should be political ones. (Searle 1993, p. 100) 
From these ideas, it is clear that the proper role of education is the search for quality and learning to differentiate the good from the bad. Tradition is important, as is intellectual independence, which is needed to avoid blindly repeating what always has been. Humanities can have a political dimension like everything else, but this is not a core value.

In his essay "Why read the classics?", Calvino presents different ideas as to why some works are considered classics. These ideas will now be applied to the PC controversy.

Calvino states that "the classics are those books which come to us bearing the aura of previous interpretations, and trailing behind them the traces they have left in the culture or cultures (or just in the language and customs) through which they have passed" (Calvino 2000, p. 5).

It is appropriate to value the classics to understand the cultures and cultural meanings and be aware of what happens in the present and what will happen in the future. It does not matter if the classic could be viewed with a different moral perspective from that of the present, because to understand a classic, it is necessary to contextualise properly. Referring to historical events, Ditakis states that "the intrinsic complexity of these historical episodes is reduced and amalgamated into a single logic: The oppression of minorities" (Dirakis 2017, p. 22). Classics should be read in the light of the era in which they are based, but at the same time should be capable of being read with a universal perspective for any time and place.

In another passage, Calvino affirms that "a classic is a work that comes before other classics; but those have read other classics immediately recognize(sic) its place in the genealogy of classic works" (Calvino 2000, p. 7).

Culture and tradition are the bedrock of common knowledge, which comes from a network of works, including classics. These classics are in themselves linked. It is not possible to explain Aristotle without Plato, Marx without Locke, and so on. Even if today's classics have special sensibility on certain topics, such as equality, these works of today are intrinsically linked with older classics that are not an egalitarian precedent. Are these older classics less classic or less worthy? The typical examples are the Enlightenment thinkers, like Hobbes, Locke and Rousseau, that are defenders of the Social Contract theory, but sexist. Some currents of Feminism try to improve the Social Contract theory in an egalitarian and inclusive way. Those Enlightenment thinkers are a precedent and are classics. They deserve to be studied in a University course with proper contextualisation.

Finally, Calvino concludes that "'your' classic is a book to which you cannot remain indifferent, and which helps you define yourself in relation or even in opposition to it" (Calvino 2000, p. 7).

This view is closely linked with PC because this movement implies that canon is under scrutiny. There are some criticisms of the classic works, which make up the canon, because they are sexist, racist and homophobic. This is an opinion of PC defenders, but it is not necessarily commonly shared. What is key here is someone has to define themselves in relation or opposition to a classic work. This is precisely the kind of critical education that University education means.

\subsection{Methodology Is Problematic}

The methodology employed by the PC movement is problematic in the sense that it is self-defeating, committing the very evils that it addresses in the work it criticises (Ayim 1998, p. 459). The two faces of PC are described by Kimball when he affirms that "this celebration of 'difference' may sound like a prescription for tolerance and genuine pluralism. But in fact, it has fostered a positively Orwellian situation in which 'diversity' really means strict intellectual conformity, and 'tolerance' is reserved exclusively for those who subscribe to one's own perspective" (Kimball 1993, p. 64).

The new prejudices based in old prejudices don't work fairly. Said explains that "the idea that because Plato and Aristotle are male and the products of a slave society they should be disqualified from receiving contemporary attention is as limited as an idea suggesting that only their work, because it was addressed to and about elites, should be read today" (Said 1993, p. 189). The methodology employed by the PC movement is problematic in the sense that it uses unjust means to get its way the 'new guard' is coercing, bullying, and silencing the 'old guard' (Ayim 1998, p. 460). 
One example of this 'new guard' is the used text in the new curriculum: The biography of Rigoberta Menchu, Guatemalan human rights activist. D'Souza asks: "If Rigoberta Menchu does not represent the actual peasant of Latin America, who does she represent? The answer is that she embodies a projection of Marxist and feminist views into South American Indian culture" (D'Souza 1991, p. 72). In an article, D'Souza adds: "Rigoberta seems to provide independent Third World corroboration from Women left-wing passion and prejudices" (D'Souza 1992, p. 15).

Multiculturalism is a new cultural imperialism for Third World countries. D'Souza affirms that "today's multicultural curriculum manipulates and amputates the Third World in precisely the same way. It subordinates the understanding of Asia, Africa, and Latin America to Western ideological prejudices. And it reflects a new cultural imperialism no less narrow and bigoted than that of the colonialist researchers in safari outfits and pith helmets" (D'Souza 1991, p. 81).

There is, therefore, an accusation of politicisation of Humanities, against multiculturalist PC. This means that "any academic purpose is secondary to political consciousness-raising. The classroom is an 'arena of struggle', and teaching should be grounded in the understanding that even teaching English composition is a political activity" (Will 1993, pp. 260-61).

Under these PC policies, D'Souza denounces that "the students appeared to share a powerful conviction that Western culture is implacably hostile to the claims of blacks, other minorities, women and homosexuals" (D'Souza 1991, pp. 59-60). This is not fair because Western culture has developed ideas and initiatives in favour of minority members. Other cultures have traditionally shown prejudices and different types of rejection over minority members. D'Souza concludes by affirming that "it seems unfair to reduce Shakespeare to a mere function of colonial, racial, and gender-related forces, Non-Western texts suffer the same indignity" (D'Souza 1991, p. 71).

Multiculturalism encourages separatism and essentialism. Wallach Scott explains that each group claims a fixed, transcendental identity and argues for its unique ability to present and interpret itself. It then established its own canon, its own history, thereby denying the relational nature of difference and the interconnectedness (Wallach Scott 1995, p. 36). Kimball states that at the centre of multiculturalist ethos is the contention that all cultures are equally valuable and, therefore, that preferring one culture is to be guilty of ethnocentrism and racism. Preferring Western culture and its heritage to others is held to be especially ethnocentric and racist (Kimball 1993, p. 64).

Another linked idea is the argument of perspectivism and all its consequences. This means literature from the perspective of the author, taking into consideration the author's gender, their race, their colour and their creed, is targeted at people of that same perspective. As Politt summarises: "[H]ow foolish to argue that Chekhov has nothing to say to a black woman—or, for that matter, myself-merely because he is Russian, long dead a man" (Politt 1992, p. 204). Again, the issue is what is the role of literature and education: Quality and enrichment or fair representation of minorities.

The conclusion on methodology issues is according to D'Souza: “[B]y reducing truth to bias, and knowledge to ideology—in short politicizing(sic) scholarship—some minority activists believe they can win greater rewards than by struggling requirements to pass traditional academic review criteria, such as publishing requirements for hiring and tenure" (D'Souza 1991, p. 185). Those are some of the proposals for changes from PC policies to Universities.

\section{Conclusive Remarks}

Some versions of multiculturalism have sought to change certain University policies and standards. It has been understood that there is a struggle for recognition of minorities perspectives. This was the beginning of the PC movement on American campuses in the 1990s.

From that decade, a great debate with the pros and cons of PC has been developed. The initial PC accusation was that the 'canon' was not neutral, but it was actually sexist, racist and homophobic. Therefore, the fair representation of minorities' perspectives in the curricula was called for. Some changes have happened from that time, such as the apparition of new courses, codes of conduct and preferential hiring policies. 
However, there are some arguments against PC. Firstly, PC is a threat to free speech. Some people argue that literary and artistic creation cannot be restricted by PC demands. This is only justifiable in very grave cases.

In the History of Ideas, there are some authors with some-today-controversial ideas, although they are classics. They cannot be removed of University curricula even if they are not now politically correct, but properly contextualise and discuss their ideas. Censorship is not the solution, but more education. Some philosophers could provide some good ideas despite other of their ideas today being considered controversial and not politically correct. These other ideas could be explained by their historical context and their ideological background. They cannot be analysed alone, but in their context.

The role of education is to search quality and to discriminate the good from the bad. Classics are books to be learnt from, even if there are parts that today have a different meaning. A classic is a book that someone can define themselves as being in favour or against.

PC's methodology is problematic because it makes the same mistakes it looks to criticise. It is a new orthodoxy with similar problems to the old orthodoxy. The claim for diversity is something superficial that actually means conformity with new ideas. The book of Rigoberta Menchu is a clear example in the new curriculum because it shows a partial and restricted view of Third World women.

The problem of perspectivism is a restricted paradigm: The idea that a particular group perspective is only worthy for this particular group of people is not sufficiently justified. It is possible to learn from different human perspectives. This is what education, especially at University level, arguably should be.

There is a current debate in different societies with cultural appropriation. This concept aims for the traditions, practices or uses of one culture, race or group to be performed only by people of these collectives. This is a type of new orthodoxy from the ideals of PC. Meanwhile, there are struggles for "real" authenticity, and this overall approach goes against fusion and hybridisation, which paradoxically are part of a good understanding of multiculturalism that is the origin of PC.

However, the topical PC's criticism that the canon was made up of only dead white male's works has been something remarkable. Diversity has been understood differently on the American campus with new courses and new voices in the curricula.

Humanity is diverse- there are different cultures and traditions, and human beings are different in certain relevant aspects, such as gender, racial or ethnic origin, religion or beliefs, sexual orientation, age, functional diversity, and so on. The notion that curricula must show this diversity could be seen, a priori, as a good idea. There is usually a certain degree of ethnocentrism at the national education systems. For example, reducing the courses of Literature and History to national authors or events, without reference to other realities. One of the criticisms of PC is the canon was comprised by dead white men. Another criticism is that those authors' works are usually sexist, racist and homophobic.

The idea of including new authors, according to diversity demands, in the curricula is interesting with certain requirements following the 'middle term' proposal: (a) Including new authors does not necessarily mean disregarding the classical authors, but to complement them; (b) those new diversity' authors must show some universal values or messages; (c) classical authors must be contextualised. This means explaining their ideas under the historical and ideological background and discussing their pros and cons; (d) A similar contextualisation exercise must be done with the new diversity' authors.

PC seeks a new understanding of diversity on campus as a part of multiculturalism. There are good arguments in favour and against these policies. It seems that a 'middle term' of PC will be desirable in which no excesses will be made based on compulsory conformity with a new orthodoxy. Instead, PC should be a realm of freedom, pluralism, and actual defence of less empowered people.

Funding: This research received no external funding.

Conflicts of Interest: The author declares no conflict of interest. 


\section{References}

Ayim, Maryann. 1998. Just how correct is Political Correctness? A critique of the opposition's arguments. Argumentation 12: 445-80. [CrossRef]

Bloom, Harold. 1987. The Closing of the American Mind. London and New York: Penguin.

Calvino, Italo. 2000. Why Read the Classics? New York: Vintage.

D'Souza, Dinesh. 1991. Illiberal Education: The Politics of Race and Sex on Campus. New York: Free Press.

D'Souza, Dinesh. 1992. The Visigoths in Tweed. In Beyond PC. Towards a Politics of Understanding. Edited by Patricia Aufderheide. Sinut Paul Minnesota: Grayfold Press.

Dirakis, Alexis. 2017. Political correctness: Implosion of Politics. Philosophies 2: 18. [CrossRef]

Doria, Manuel. 2017. The unreasonable destructiveness of Political Correctness in Philosophy. Philosophies 2: 17. [CrossRef]

Finnis, John. 1996. Is Natural Law Theory compatible with limited government? In Natural Law, Liberalism and Morality. Contemporary Essay. Edited by Robert P. George. Oxford: Clarendon Press, pp. 1-26.

Giroux, Henry. 1995. Academics as public intellectuals: Rethinking classrooms politics. In C Wars. Politics and Theory in the Academy. Edited by Jeffrey Williams. New York and London: Routledge, pp. 294-307.

Gordon, Ted, and Wahneema Lubiano. 1993. The statement of the Black Faculty Caucus. In Debating PC. The Controversy over Political Correctness on College Campuses. Edited by Paul Berman. New York: Laurel, pp. 249-57.

Howe, Irving. 1993. The value of the canon. In Debating PC. The Controversy over Political Correctness on College Campuses. Edited by Paul Berman. New York: Laurel, pp. 153-71.

Kimball, Roger. 1998. Tenured Radicals: How Politics Corrupted Our Higher Education. New York: Harper Collins.

Kimball, Roger. 1993. The Periphery v. the Center: The MLA in Chicago. In Debating PC. The Controversy over Political Correctness on College Campuses. Edited by Paul Berman. New York: Laurel, pp. 61-84.

Lichev, Valeri, and Miroslava Hristoskova. 2017. Political correctness. Between fiction and social reality. Philosophies 2: 15. [CrossRef]

Magnani, Lorenzo. 2016. Political correctness between wise stoicism and violent hypocrisy. Philosophies 1: 261. [CrossRef]

Neilson, James. 1995. The great PC Scare: Tyrannies of the Left, rhetoric of the right. In PC Wars. Edited by Jeffrey Williams. New York and London: Routledge, pp. 60-89.

Perry, Ruth. 1992. A short history of the term Politically Correct. In Beyond PC. Towards a Politics of Understanding. Edited by Patricia Aufderheide. Saint Paul Minnesota: Grayfold Press, pp. 71-79.

Politt, Katha. 1992. Why do we read? In Debating PC. The Controversy over Political Correctness on College Campuses. Edited by Paul Berman. New York: Laurel, pp. 201-14.

Rothenberg, Paula. 1993. Critics of attempts to democratize the curriculum are waging a campaign to misrepresent the work of responsible professors. In Debating PC. The Controversy over Political Correctness on College Campuses. Edited by Paul Berman. New York: Laurel, pp. 262-70.

Said, Edward W. 1993. The Politics of knowledge. In Debating PC. The Controversy over Political Correctness on College Campuses. Edited by Paul Berman. New York: Laurel, pp. 172-89.

Searle, John. 1993. The storm over the University. In Debating PC. The Controversy over Political Correctness on College Campuses. Edited by Paul Berman. New York: Laurel, pp. 85-123.

Stimpson, Catharine. 1992. On differences: Modern language Association Presidential Address 1990. In Debating PC. The Controversy over Political Correctness on College Campuses. Edited by Paul Berman. New York: Laurel, pp. 40-60.

Taylor, Charles. 1994. The Politics of recognition. In Multiculturalism and the Politics of Recognition. Edited by Amy Gutmannn. Princeton: Pricenton University Press, pp. 25-74.

Wallach Scott, Joan. 1995. The campaign against political correctness. In PC Wars. Politics and Theory in the Academy. Edited by Jeffrey Williams. New York and London: Routledge, pp. 22-43.

Will, George F. 1992. Literary politics. In Beyond PC. Towards a Politics of Understanding. Edited by Patricia Aufderheide. Saint Paul Minnesota: Grayfold Press, pp. 23-26.

Will, George F. 1993. Radical English. In Debating PC. The Controversy over Political Correctness on College Campuses. Edited by Paul Berman. New York: Laurel, pp. 258-61. 
Young, Iris Marion. 1990. Justice and Politics of Difference. Princeton: Princeton University Press. Young, Iris Marion. 2002. Inclusion and Democracy. Oxford: Oxford University Press.

(C) 2019 by the author. Licensee MDPI, Basel, Switzerland. This article is an open access article distributed under the terms and conditions of the Creative Commons Attribution (CC BY) license (http://creativecommons.org/licenses/by/4.0/). 